Journal of

(C) All rights are reserved by Ugwoha,et al.

\title{
Effect of Soil Type on the Fate of Kerosene Compounds in the Presence of Water and Ethanol
} \section{Chinemerem B. Okoronkwo}

Ejikeme Ugwoha*, Chindo A. Nwankwo and

Department of Environmental Engineering, University of Port Harcourt, PMB 5323, Nigeria

\begin{abstract}
Keywords: Lysimeter experiment; Transport; Sorption; Kerosene; Ethanol

Abstract

The effect of soil type on the fate of kerosene compounds in the presence of waterand ethanol wasstudied. Mini lysimeter experiments were conducted to compare the transport and sorption of kerosene compounds in different soil types, namely sand, silt and clay. The soils were artificially contaminated with $7 \%(w / w)$ kerosene in the absence and presence of ethanol. Rainfall simulation was performed until zero concentration of kerosene compounds was observed in the effluent. The results obtained showed significant variations in the transport and sorption of kerosene compounds in the different soil types. Benzene $(11.9,8.9$, and $5.5 \mathrm{mg} / \mathrm{l})$, tolvene $(10.9,8.6$ and $6.3 \mathrm{mg} / \mathrm{l})$ and $x y l e n e$ $(12.8,8.5$ and $5.8 \mathrm{mg} / \mathrm{l})$ were leached in sand, silt, and clay, respectively. Conversely, benzene $(3.0,5.3$, and $7.8 \mathrm{mg} / \mathrm{kg})$, tolvene $(4.0,5.5$ and 9.6 $\mathrm{mg} / \mathrm{kg}$ ) and xylene $(4.7,6.4$ and $9.1 \mathrm{mg} / \mathrm{kg}$ ) were retained in sand, silt and clay, respectively. Generally, the transport of the kerosene compounds in the different soil types was in the order of sand>silt>clay, while the retention was in the order of clay>silt>sand. The sorption coefficient $\left(K_{d}\right)$ and retardation factor $(R)$ were found to be in the order of xylene>tolvene>benzene for the kerosene compounds, and in the order of clay $>$ silt $>$ sand for the soil types. The presence of ethanol enhanced the transport of the kerosene compounds but reduced their somtion, $K_{d}$ and $R$, to varying percentages, ranging from 12 to $76 \%$. These effects were generally greatest in sand except in the case of $R$ where it was in clay, and generally affected xylene more than the other aromatic kerosene compounds.
\end{abstract}

\section{Introduction}

Soil contamination with crude oil products is a major concern in both developing and developed countries [1]. Contamination of soil with crude oil products can adversely affect the soil microbes and plants as well as contaminate groundwater resources. According to Hsieh et al. groundwater plays a crucial role as a source of drinking water and accounts for nearly $80 \%$ of the rural domestic water needs and $50 \%$ of the urban water needs [2]. Because soil frequently serves as the site of petroleum products' spills, the capacity of the soil to filter, retain, or release hydrocarbons is fundamental in determining the type and extent of groundwater contamination [1].

Kerosene is one of the most widely used crude oil products in our society today [3]. In many developing countries, kerosene is an important source of energy for cooking and lighting. It is also used as a heat source during power failures and very preferred as a combustion fuel due to its availability and accessibility [4-6]. Kerosene is also used as a solvent (e.g. in cleaners, pesticides and paints) and degreaser, and has been used to control mosquito larvae [4]. World total kerosene consumption for all purposes is equivalent to about 1.2 million barrels per day [7]. However, due to its regular and increased use in many homes today, a considerable amount is released to the environment $[3,8]$. In Nigeria, petroleum products are mostly transported by land and this has increased the risk of

\section{*Address for Correspondence}

Ejikeme Ugwoha, Department of Environmental Engineering, University of Port Harcourt, PMB 5323, Nigeria, Tel: 080 31181050; E-mail: ugwohaej@yahoo.com

Submission: 05 April, 2016

Accepted: 30 April, 2016

Published: 06 May, 2016

Copyright: $\odot 2016$ Ugwoha E. This is an open access article distributed under the Creative Commons Attribution License, which permits unrestricted use, distribution, and reproduction in any medium, provided the original work is properly cited.

Reviewed \& Approved by: Dr. Mark Meo, Department of Geography \& Environmental Sustainability, University of Oklahoma, USA

spillage due to bad road networks. After an accidental release to the soil, the persistence of kerosene compounds in the vadose zone, their migration to groundwater and the scale of contamination expected in the groundwater are problems of particular environmental concern. This requires the knowledge of the sorption characteristics of the kerosene compounds in the soil as well as the knowledge of the soil type and characteristics. Such knowledge will be vital for the successful development and applications of fate and transport models to practical situations [9]. Therefore, understanding the behaviour of kerosene in the environment following release is essential as such knowledge could be used to predict the extent of groundwater contamination.

When released into the environment via accidental spills and leakages, the relatively water soluble compounds in kerosene, such as benzene, toluene, xylenes, will tend to quickly migrate to groundwater thereby contaminating it. However, the depth to the water table which is equivalent to the thickness of the vadose zone is one of the parameters that determine whether or not a contaminant will reach the water table from a surface spill. Therefore, at any contaminated site, the vadose zone needs to be characterised for effective prediction of the contaminant's fate. Soils that are porous and permeable tend to transmit water and certain types of contaminants with relative ease to an aquifer below. Generally, the greater the distance between a source of contamination and a groundwater source, the more likely that natural processes will reduce the impacts of contamination. Processes such as oxidation, biological degradation, and adsorption may take place in the soil layers of the vadose zone and reduce the concentration of a contaminant before it reaches groundwater. Once in groundwater, these kerosene compounds can contribute to long term hazards [10].

Kerosene is a combustible hydrocarbon liquid with a density of $0.80 \mathrm{~g} / \mathrm{cm}^{3}$ and obtained from the fractional distillation of petroleum between $145^{\circ} \mathrm{C}$ and $300{ }^{\circ} \mathrm{C}[5,6]$. It is a valuable hydrocarbon used as fuel in stoves and lamps in many homes in Nigeria. The major 
Citation: Ugwoha E, Nwankwo CA, Okoronkwo CB. Effect of Soil Type on the Fate of Kerosene Compounds in the Presence of Water and Ethanol. J Environ Stud. 2016;2(1): 8.

harmful compounds in kerosene include benzene, toluene and xylenes [7]. These compounds have harmful effects on the central nervous system; some are carcinogenic as well. The amount of benzene, toluene and xylene is sometimes used as a tool in assessing the relative risks or seriousness at contaminated locations and the need for remediation of such site [11]. Kerosene is a hydrophobic hydrocarbon product and its insolubility in water tends to affect its behaviour when released in the environment [12]. On the contrary, ethanol which is also a commonly used hydrocarbon product is highly soluble in water and its hydrophilic nature could alter the sorption and transport properties of kerosene in the vadose zone when they are simultaneously released.

In this study, mini lysimeter experiments were carried out to investigate the behaviour of kerosene compounds in the absence and presence of ethanol in the vadose zone with different soil types. The kerosene compounds examined were benzene, xylene and toluene. The soils were artificially contaminated with $7 \%(\mathrm{w} / \mathrm{w})$ kerosene in the absence and presence of ethanol, and rainfall simulation was performed until zero concentration of the kerosene compounds was observed in the effluent. The total concentration of each kerosene compound that got leached and the concentration that was retained in the soil were estimated for the different soil types.

\section{Materials and Methods}

\section{Kerosene and ethanol}

The kerosene used in this study was procured from Total Petrol Station in Port Harcourt. The kerosene compounds of interest were benzene, toluene, and m-xylene (Table 1). These compounds were chosen because of their health related problems to human. The kerosene sample was first analysed in the laboratory to identify the initial concentration of the compounds of interest. The ethanol used was of high purity (96\%) and obtained from a Petrochemical Retail Outlet in Port Harcourt. The purpose of using ethanol in this study was to determine its effect on the sorption and transport of kerosene compounds in the vadose zone [13]. Other details of the ethanol are

Table 1: Kerosene compounds and ethanol.

\begin{tabular}{|c|c|c|c|c|c|c|}
\hline Compound & Formula & $\begin{array}{l}\text { Conc. in } \\
\text { kerosene, } \\
\text { mg/l }\end{array}$ & $\begin{array}{l}\text { Density } \\
\text { at } 25^{\circ} \mathrm{C}, \\
\mathrm{g} / \mathrm{ml}^{\mathrm{a}}\end{array}$ & $\begin{array}{l}\text { Water } \\
\text { solubility } \\
\text { at } 25^{\circ} \mathrm{C} \text {, } \\
\mathrm{mg} / \mathrm{l}^{\mathrm{a}}\end{array}$ & $\begin{array}{l}\text { Henry's } \\
\text { law const. } \\
\text { at } 25^{\circ} \mathrm{C} \text {, - a }\end{array}$ & $\mathrm{K}_{\mathrm{ow}}{ }^{\mathrm{a}}$ \\
\hline Benzene & $\mathrm{C}_{6} \mathrm{H}_{6}$ & 15.83 & 0.8765 & 1790 & 0.217 & 134.9 \\
\hline Toluene & $\mathrm{C}_{7} \mathrm{H}_{8}$ & 17.70 & 0.8667 & 556 & 0.244 & 537.0 \\
\hline m-Xylene & $\mathrm{C}_{8} \mathrm{H}_{10}$ & 19.69 & 0.8640 & 158 & 0.260 & $1,584.9$ \\
\hline Ethanol & $\mathrm{C}_{2} \mathrm{H}_{5} \mathrm{OH}$ & - & $0.789^{b}$ & Total $^{\mathrm{b}}$ & $2.94^{\star} 10^{-4 b}$ & $0.5^{b}$ \\
\hline
\end{tabular}

a values obtained from Christophersen et al. (2005);

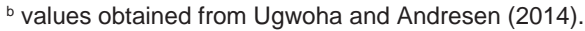

Table 2: Soil type and characteristics.

\begin{tabular}{|c|c|c|c|c|}
\hline \multirow[b]{2}{*}{ Soil type } & \multicolumn{4}{|c|}{ Characteristics } \\
\hline & PSD, mm & $\begin{array}{l}\text { Particle density, g/ } \\
\text { cm }^{3}\end{array}$ & Bulk density, $\mathrm{g} / \mathrm{cm}^{3}$ & Porosity \\
\hline Sand & $0.1-2.0$ & 2.65 & 1.60 & 0.39 \\
\hline Silt & 0.01- 0.1 & 2.79 & 1.34 & 0.48 \\
\hline Clay & $<0.01$ & 2.83 & 1.18 & 0.56 \\
\hline
\end{tabular}

PSD: Particle Size Distribution summarised in Table 1.

\section{Soil description}

The soils used in this study were obtained from University of Port Harcourt and comprised sand, silt and clay, representing varying soil drainage characteristics. The soil samples were air dried and sieved using a $2 \mathrm{~mm}$ sieve to obtain a uniform particle size and classification of all the soil types. The soils were analysed for the presence of benzene, toluene and $\mathrm{m}$-xylene, and the concentrations obtained were used as the baseline concentrations. Table 2 summarizes the characteristics of the soil types used.

\section{Experimental setup}

Mini lysimeter experiments were performed to investigate the transport and sorption of kerosene compounds in sand, silt, and clay. The lysimeter used was as designed and reported in our previous study [14]. The sample collection and analysis were also performed following Ugwoha et al. [14]. A $2 \mathrm{~cm}$ depth layer of uncontaminated fine gravels, obtained from Port Harcourt, was placed in the bottom of the lysimeter and uniformly levelled. The soils were placed into the lysimeter in turns to a height of $15 \mathrm{~cm}$, corresponding to the average depth of $32 \mathrm{~m}$ unsaturated zone in most Port Harcourt areas $(5 \mathrm{~cm}$ soil in the lysimeter representing $8 \mathrm{~m}$ depth of the unsaturated zone). The total volume of each soil used was $1425 \mathrm{~cm}^{3}$. The remaining $3 \mathrm{~cm}$ void of the lysimeter prevented the overflow of accumulated rainfallsimulated water.

After packing the soil into the lysimeter, water was released on the soil, via the rain simulator, until it was saturated and then allowed for 2 days to attain water content equivalent to field capacity hence imitating soil in a natural environment. Thereafter, $100 \mathrm{ml}$ of kerosene, representing $7 \%$ volume of soil, was released on the soil in one set of experiments, and $100 \mathrm{ml}$ of kerosene as well as $50 \mathrm{ml}$ of ethanol, representing 50\% volume of kerosene, were released consecutively on the soil in another set of experiments. Then, $250 \mathrm{ml}$ water, a volume found appropriate to wet the $15 \mathrm{~cm}$ height soil during a pilot experiment, was released to simulate rainfall. The rainfall simulation continued in batches until kerosene compounds were not detected in the effluent. Finally, the soil was analysed to know the quantity of kerosene compounds retained.

Before contamination, the soil samples and water used were analysed for background concentrations of kerosene compounds. After contamination and the first rainfall simulation, the first effluent was collected. About two hours after the first effluent had ceased the second rainfall simulation and hence second effluent collection followed. This continued in the same manner until there was no trace of kerosene compounds in the effluent. The $15 \mathrm{~cm}$ height of soil was divided into two layers of $7.5 \mathrm{~cm}$ each, and samples of soil collected from the two layers.

The collected effluent and soil samples were analysed using a Genesys 10 uv Sample Reader Spectrophotometer. The setting and operation of the Spectrophotometer as well as the preparation of water and soil samples were as described in our previous study [14]. However, in this study, absorbance was measured by setting the Spectrophotometer at $212 \mathrm{~nm}$ for benzene, $250 \mathrm{~nm}$ for toluene and $220 \mathrm{~nm}$ for xylene. The concentration of kerosene compounds 
Citation: Ugwoha E, Nwankwo CA, Okoronkwo CB. Effect of Soil Type on the Fate of Kerosene Compounds in the Presence of Water and Ethanol. J Environ Stud. 2016;2(1): 8.

in the samples was calculated using the Beer's law which states that the absorbance of a light absorbing material is proportional to its concentration in solution.

\section{Estimation of water infiltration rate, sorption coefficient and retardation factor}

The water infiltration rate (WIR) in the soils, sorption coefficient $\left(\mathrm{K}_{\mathrm{d}}\right)$ and retardation factor $(\mathrm{R})$ of kerosene compounds were estimated using the procedure reported in Ugwoha et al. [14]. Accordingly, WIR was estimated using Equation (1), $K_{d}$ was calculated from the measured soil and effluent concentrations using Equation (2), and $\mathrm{R}$ was estimated using Equation (3).

$$
\begin{gathered}
W I R=\frac{D I}{t} \\
K_{d}=\frac{C_{s}}{C_{w}} \\
R=1+\frac{\rho}{n} K_{d}
\end{gathered}
$$

where, DI is the distance infiltrated $(15 \mathrm{~cm}), \mathrm{t}$ is the time taken, $\mathrm{C}_{\mathrm{s}}$ is the concentration of kerosene compound in soil $(\mathrm{mg} / \mathrm{kg}), \mathrm{C}_{\mathrm{w}}$ is the concentration of kerosene compound in water (effluent) $(\mathrm{mg} / \mathrm{L}), \rho$ is the bulk density of the unsaturated zone material $(\mathrm{g} / \mathrm{cm})$, and $\mathrm{n}$ is the porosity of the simulated unsaturated zone (dimensionless).

\section{Results and Discussion}

\section{Baseline measurements}

Table 3 shows the results of the baseline measurements conducted prior to contamination. There were little amounts of benzene (0.62$1.02 \mathrm{mg} / \mathrm{l})$ and toluene $(0.72-0.98 \mathrm{mg} / \mathrm{l})$ present in the three soils. Xylene was however found to be present only in clay $(0.86 \mathrm{mg} / \mathrm{l})$. These concentrations were subtracted from the resulting sample concentrations after the leaching experiment to ensure accuracy. Both the water infiltration rate and hydraulic conductivity of the soils
Table 3: Soil baseline measurements.

\begin{tabular}{|l|l|l|l|l|l|}
\hline Soil & $\begin{array}{l}\text { Benzene } \\
(\mathbf{m g} / \mathbf{l})\end{array}$ & $\begin{array}{l}\text { Toluene } \\
(\mathbf{m g} / \mathbf{l})\end{array}$ & $\begin{array}{l}\text { Xylene } \\
(\mathbf{m g} / \mathbf{l})\end{array}$ & $\begin{array}{l}\text { WIR } \\
(\mathbf{c m} / \mathbf{m})\end{array}$ & $\begin{array}{l}\text { Hydraulic conductivity } \\
(\mathbf{c m} / \mathbf{m})\end{array}$ \\
\hline Sand & 0.62 & 0.72 & n.d & 1.40 & 0.35 \\
\hline Silt & 0.72 & 0.90 & n.d & 1.00 & 0.21 \\
\hline Clay & 1.02 & 0.98 & 0.86 & 0.56 & 0.14 \\
\hline
\end{tabular}

n.d: Not detected

were in the order of sand $>$ silt $>$ clay. According to Ugwoha et al. these differences in the water infiltration rate and hydraulic conductivity of the soils imply that the migration of contaminants in the soils will differ [14].

\section{Transport of kerosene compounds}

The transport of kerosene compounds in the various soils during leaching is shown in Figure 1. The concentration of kerosene compounds in effluent decreased with increased rainfall simulations. Generally, the leaching of kerosene compounds from soils was in the order of sand $>$ silt $>$ clay. A total of $11.9 \mathrm{mg} / \mathrm{l}, 8.9 \mathrm{mg} / \mathrm{l}$, and 5.5 $\mathrm{mg} / \mathrm{l}$ benzene, $10.9 \mathrm{mg} / \mathrm{l}, 8.6 \mathrm{mg} / \mathrm{l}$ and $6.3 \mathrm{mg} / \mathrm{l}$ toluene, and 12.8 $\mathrm{mg} / \mathrm{l}, 8.5 \mathrm{mg} / \mathrm{l}$ and $5.8 \mathrm{mg} / \mathrm{l}$ xylene, were leached from sand, silt, and clay, respectively. Therefore, the transport of kerosene compounds to groundwater after accidental release will be greater with coarsetextured soils than with fine-textured soils.

The transport of kerosene compounds in the various soils in the presence of ethanol is shown in Figure 2. As observed with kerosene alone, the concentration of kerosene compounds in effluent also decreased with increased rainfall simulations and the leaching of compounds was also in the order of sand $>$ silt $>$ clay. However, the presence of ethanol increased the quantity of the kerosene compounds leached from the different soils. A total of $16.1 \mathrm{mg} / \mathrm{l}, 13.9 \mathrm{mg} / \mathrm{l}$ and $10.9 \mathrm{mg} / \mathrm{l}$ benzene, $15.0 \mathrm{mg} / \mathrm{l}, 13.1 \mathrm{mg} / \mathrm{l}$ and $8.7 \mathrm{mg} / \mathrm{l}$ toluene, and $16.2 \mathrm{mg} / \mathrm{l}, 13.7 \mathrm{mg} / \mathrm{l}$ and $8.5 \mathrm{mg} / \mathrm{l}$ xylene, were leached from sand, silt and clay, respectively. The presence of ethanol increased the leaching of the kerosene compounds by $25 \%, 20 \%$, and $16 \%$ for benzene, $25 \%$, $14 \%$ and $16 \%$ for toluene, and $22 \%, 15 \%$ and $12 \%$ for xylene, in sand, silt and clay, respectively. Therefore, a concomitant or consecutive accidental release of kerosene and ethanol on any soil will result in a greater contamination of the underlying groundwater by the

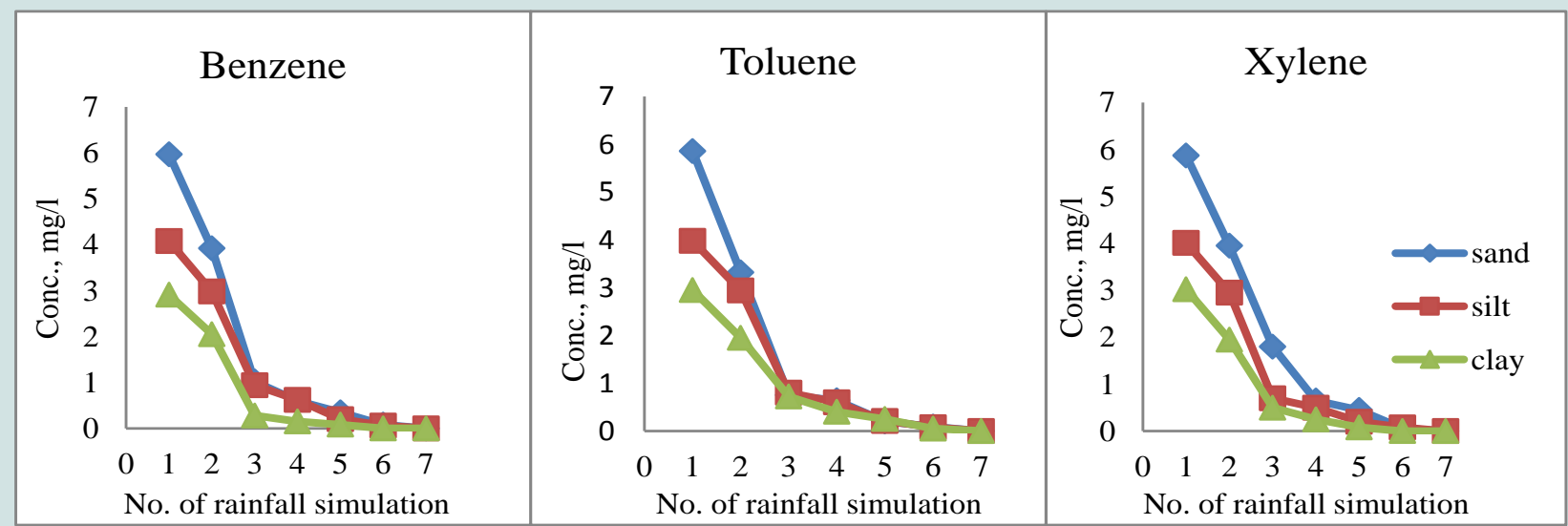

Figure 1: Transport of kerosene compounds in different soil types. 
Citation: Ugwoha E, Nwankwo CA, Okoronkwo CB. Effect of Soil Type on the Fate of Kerosene Compounds in the Presence of Water and Ethanol. J Environ Stud. 2016;2(1): 8.

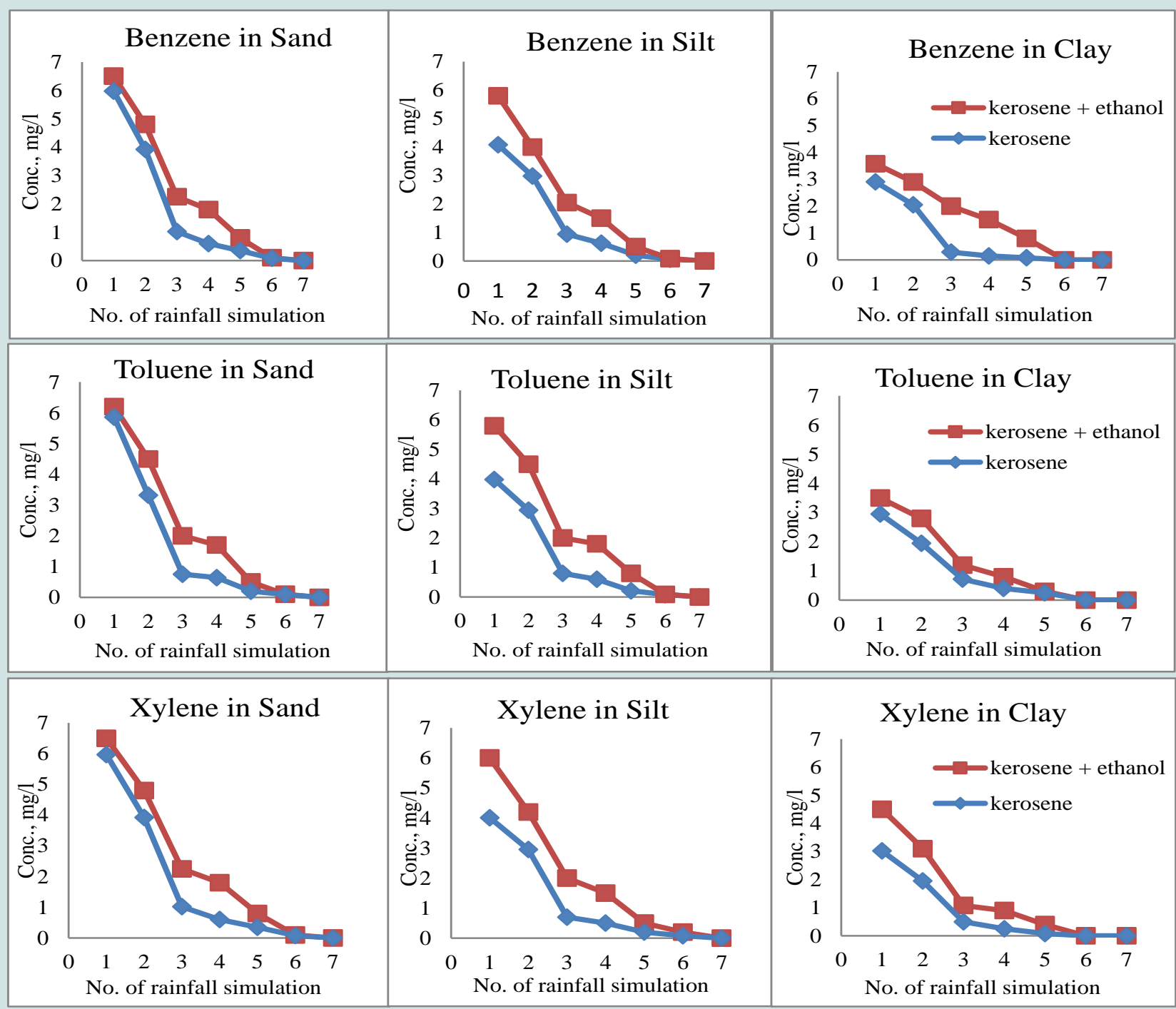

Figure 2: Transport of kerosene compounds in different soil types in the presence and absence of ethanol.

kerosene compounds.

\section{Sorption of kerosene compounds}

The result of the sorption of kerosene compounds in the different soils is presented in Figure 3. A total of $3.0 \mathrm{mg} / \mathrm{kg}, 5.3 \mathrm{mg} / \mathrm{kg}$ and $7.8 \mathrm{mg} / \mathrm{kg}$ benzene, $4.0 \mathrm{mg} / \mathrm{kg}, 5.5 \mathrm{mg} / \mathrm{kg}$ and $9.6 \mathrm{mg} / \mathrm{kg}$ toluene, and $4.7 \mathrm{mg} / \mathrm{kg}, 6.4 \mathrm{mg} / \mathrm{kg}$ and $9.1 \mathrm{mg} / \mathrm{kg}$ xylene, were retained in sand, silt and clay, respectively. Generally, the sorption of the kerosene compounds was in the order of clay $>$ silt $>$ sand, and the upper layer of the soils retained most of these compounds. Therefore, the groundwater underneath clay soil is likely to be less contaminated by kerosene compounds after accidental release than the groundwater underneath silt and sand.

Figure 4 shows the result of the sorption of kerosene compounds in the presence of ethanol. Generally, the retention of the kerosene compounds was also in the order of clay $>$ silt $>$ sand, and the upper layer of the soils also retained most of these compounds. However, the presence of ethanol reduced the quantity of the kerosene compounds retained in the different soil types. A total of $1.9 \mathrm{mg} / \mathrm{kg}, 3.1 \mathrm{mg} / \mathrm{kg}$ and $6.1 \mathrm{mg} / \mathrm{kg}$ benzene, $2.4 \mathrm{mg} / \mathrm{kg}, 4.1 \mathrm{mg} / \mathrm{kg}$ and $6.1 \mathrm{mg} / \mathrm{kg}$ toluene, and $1.5 \mathrm{mg} / \mathrm{kg}, 2.9 \mathrm{mg} / \mathrm{kg}$ and $5.9 \mathrm{mg} / \mathrm{kg}$ xylene, were retained in sand, silt and clay, respectively. The presence of ethanol reduced the concentration of the kerosene compounds retained by $37 \%, 42 \%$ and $22 \%$ for benzene, $40 \%, 25 \%$ and $36 \%$ for toluene, and $68 \%, 55 \%$ and $35 \%$ for xylene, in sand, silt and clay, respectively. This effect was generally greater in sand among the soil types, and greater for xylene among the kerosene compounds. Therefore, in the presence of ethanol, xylene will likely cause greater groundwater contamination than other aromatic kerosene compounds.

\section{Sorption coefficient in soils}

The sorption coefficient $\left(\mathrm{K}_{\mathrm{d}}\right)$ of kerosene compounds in different soils as obtained from Equation (2) is shown in Figure $5 . K_{d}$ relates to the distribution of a contaminant between the soil solids and soil water [10]. The $\mathrm{K}_{\mathrm{d}}$ values of all kerosene compounds varied in 
Citation: Ugwoha E, Nwankwo CA, Okoronkwo CB. Effect of Soil Type on the Fate of Kerosene Compounds in the Presence of Water and Ethanol. J Environ Stud. 2016;2(1): 8.
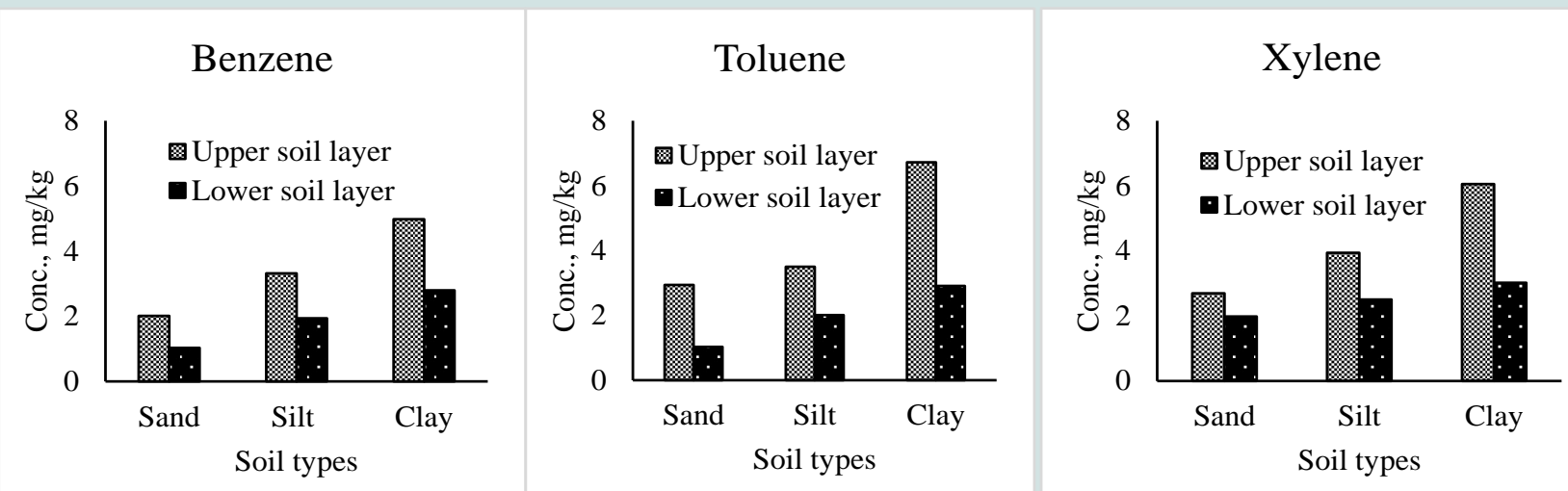

Figure 3: Retention of kerosene compounds in the different layers of various soil types.

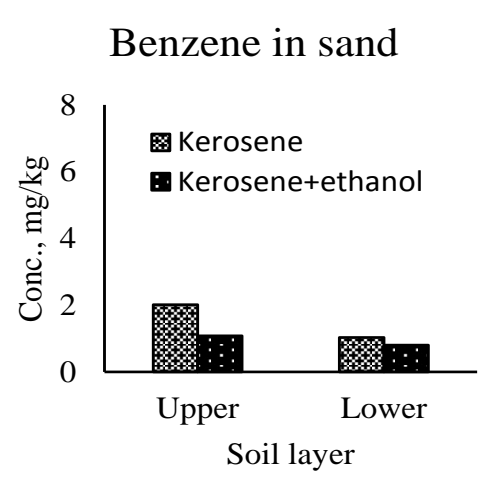

Toluene in sand

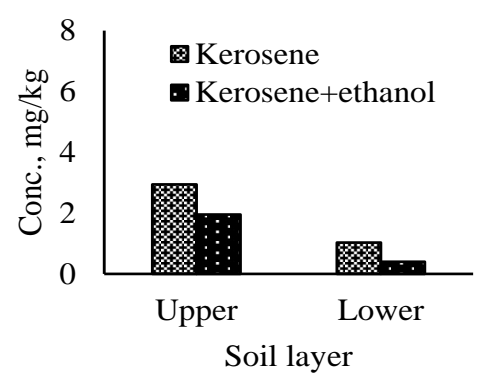

$X$ ylene in sand

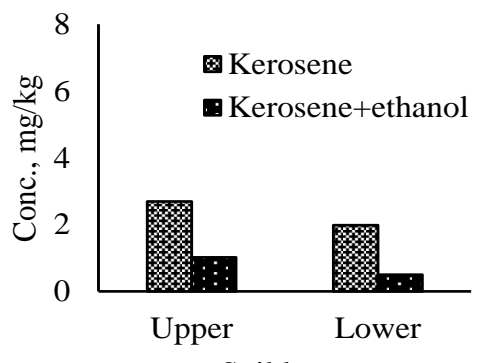

Soil layer
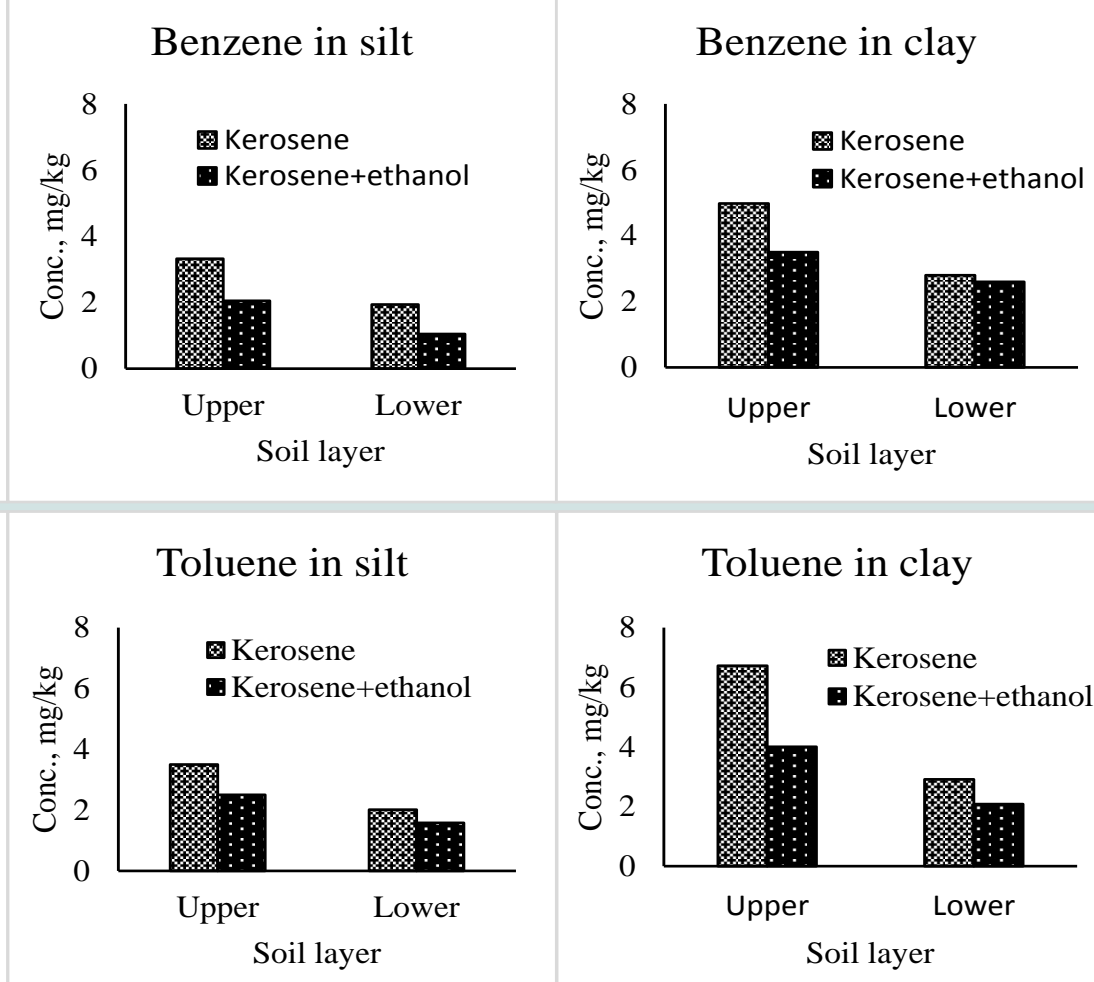

Toluene in clay
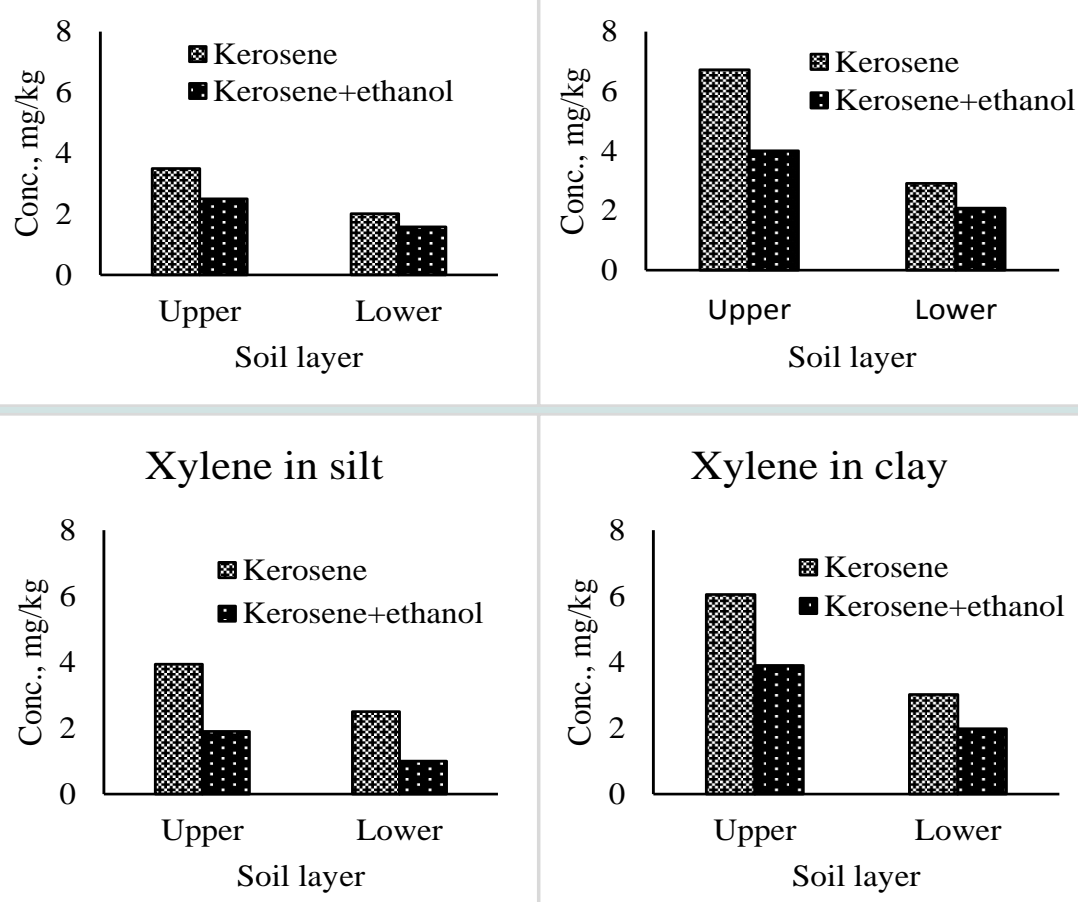

X ylene in clay

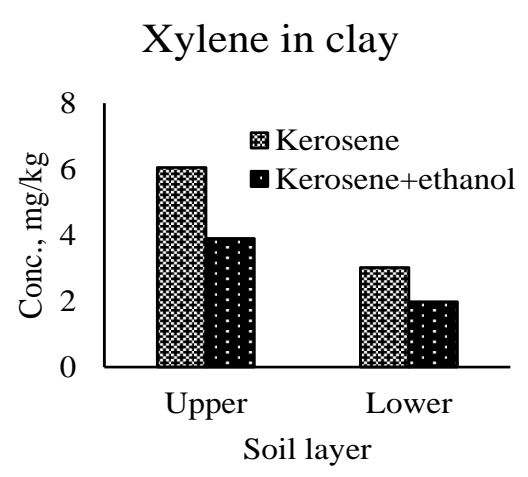

Figure 4: Retention of kerosene compounds in the different layers of various soil types in the presence and absence of ethanol. 
Citation: Ugwoha E, Nwankwo CA, Okoronkwo CB. Effect of Soil Type on the Fate of Kerosene Compounds in the Presence of Water and Ethanol. J Environ Stud. 2016;2(1): 8.

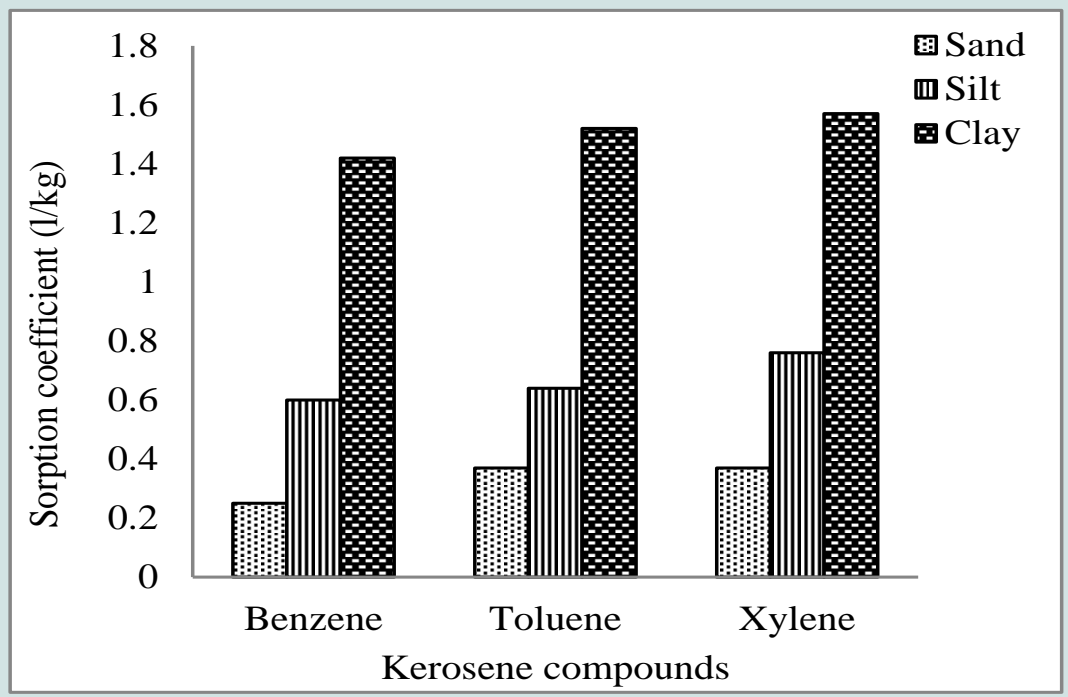

Figure 5: Sorption coefficient of kerosene compounds in different soil types.
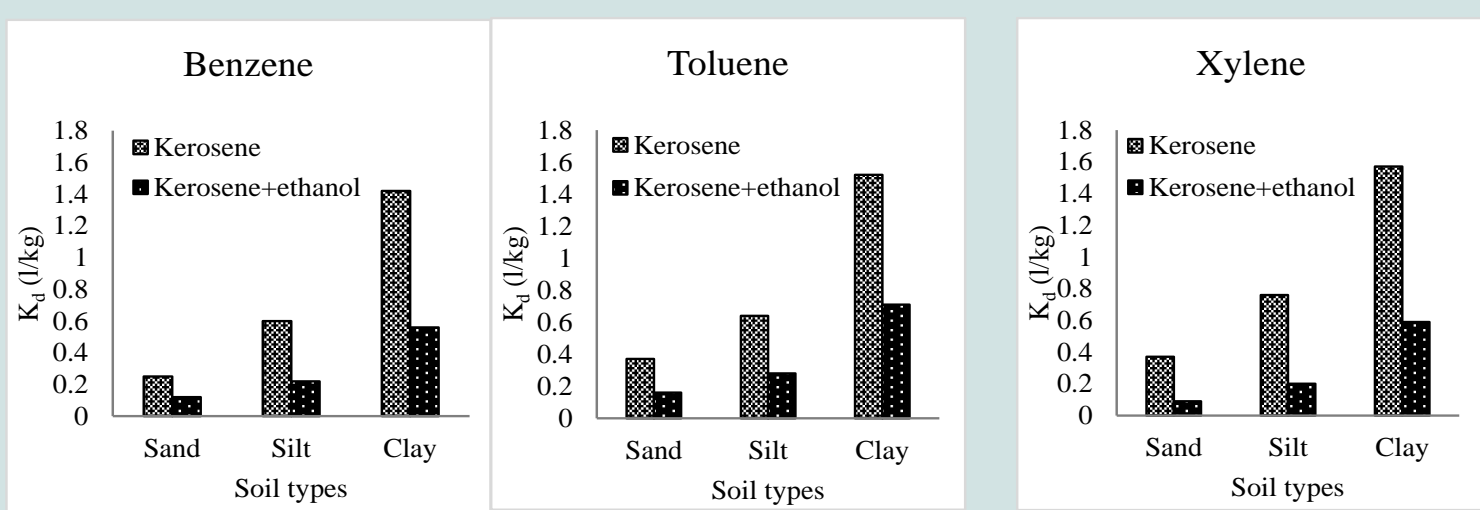

Figure 6: Sorption coefficient of kerosene compounds in different soil types in the presence and absence of ethanol.

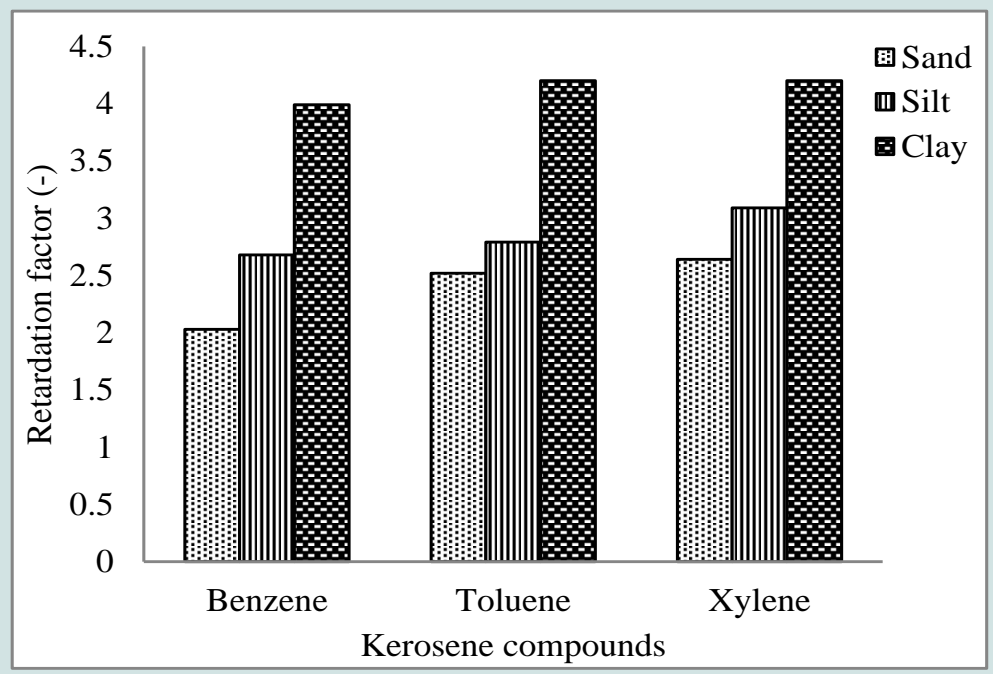

Figure 7: Retardation factors of kerosene compounds in different soils. 


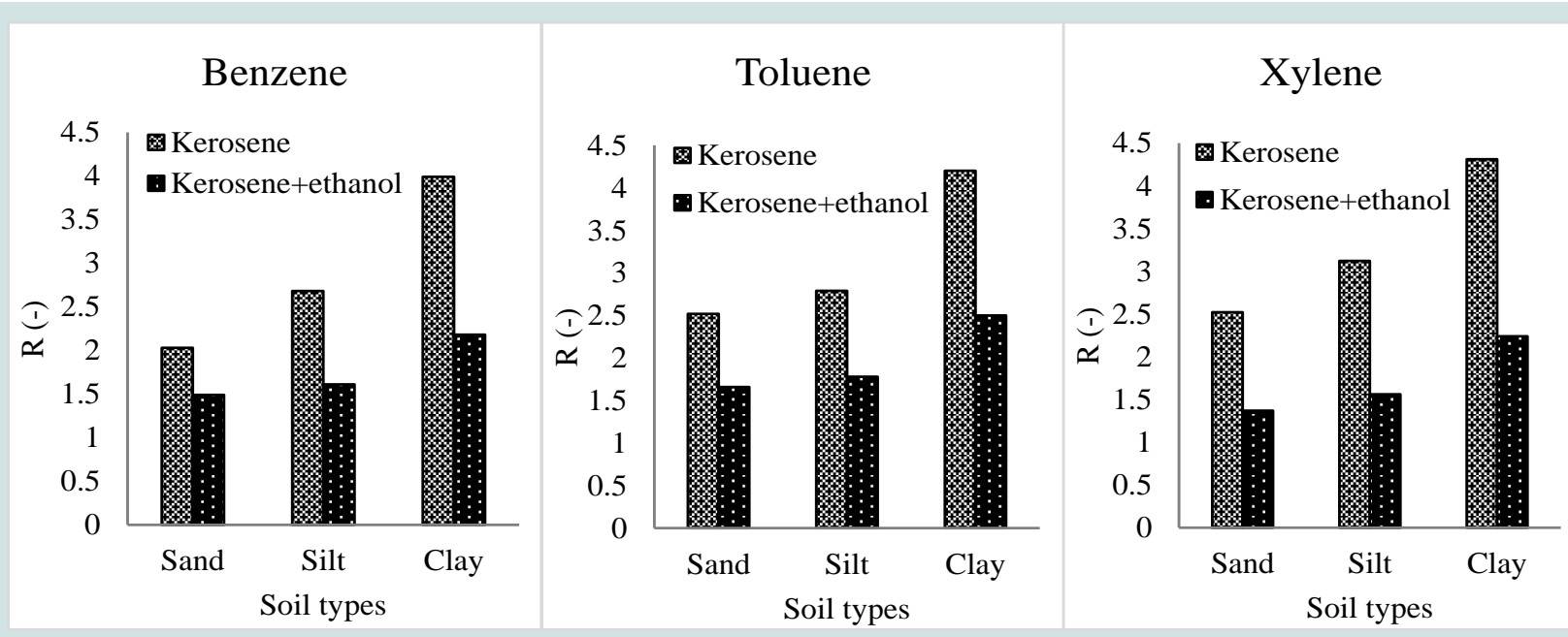

Figure 8: Retardation factor of kerosene compounds in different soil types in the presence and absence of ethanol.

different soils. Generally, the $\mathrm{K}_{\mathrm{d}}$ of kerosene compounds in the tested soil types was in the order of clay>silt $>$ sand, implying that a higher percentage of kerosene compounds will be retained by clay than by silt or sand following kerosene release. Among the kerosene compounds, $\mathrm{K}_{\mathrm{d}}$ was in the order of xylene>toluene>benzene, implying that a higher percentage of xylene will be retained by soil solids than leached by soil water relative to toluene and benzene. Considering that the number of carbon atoms in xylene, toluene and benzene are 8, 7 and 6, respectively, it can be inferred that hydrocarbon chains with higher carbon atoms are likely to have higher sorption coefficients than those with fewer carbon atoms. This agrees with the findings of CONCAWE that hydrocarbon chains with lower carbon atoms tend to have lower partition coefficients than those with higher carbon numbers [15].

Figure 6 shows the result of the $K_{d}$ of kerosene compounds in the presence of ethanol. The presence of ethanol reduced the $K_{d}$ of all the kerosene compounds in all the three soil types used. The $\mathrm{K}_{\mathrm{d}}$ of the kerosene compounds decreased by $52 \%, 63 \%$ and $61 \%$ for benzene, $57 \%, 56 \%$ and $53 \%$ for toluene, and $76 \%, 74 \%$ and $62 \%$ for xylene, in sand, silt and clay, respectively. This effect was in the order of sand>clay>silt among the soil types, and in the order of xylene $>$ benzene $>$ toluene among the kerosene compounds. Therefore, in the presence of ethanol, xylene will likely cause greater groundwater contamination than other aromatic kerosene compounds. Such contamination is likely to be worst in sand relative to clay and silt.

\section{Retardation factor of kerosene compounds in soils}

The retardation factor $(\mathrm{R})$ of kerosene compounds in different soils as obtained from Equation (3) is shown in Figure 7. R represents the degree of retardation of the migration of a contaminant due to sorption [10]. Like the $K_{d}$ values, the $R$ values of all kerosene compounds in soils was in the order of clay $>$ silt $>$ sand, implying that kerosene compounds will be retarded most by clay and least by sand following kerosene release. In all the soil types tested, $\mathrm{R}$ of kerosene compounds was in the order of xylene>toluene>benzene, indicating that xylene is likely to be retarded more than toluene or benzene in soils. In other words, xylene is likely to be transported the least distance in soils over a given time than toluene and benzene. Thus, xylene is likely to cause less groundwater contamination than toluene and benzene after an accidental release of kerosene.

Figure 8 shows the result of the $\mathrm{R}$ of kerosene compounds in the presence of ethanol. The presence of ethanol reduced the $\mathrm{R}$ of all kerosene compounds in all the soil types tested. The $\mathrm{R}$ of the kerosene compounds decreased by $27 \%, 40 \%$ and $45 \%$ for benzene, $34 \%, 36 \%$ and $40 \%$ for toluene, and $46 \%, 50 \%$ and $48 \%$ for xylene, in sand, silt and clay, respectively. In all the soil types tested, this effect was found to be in the order of xylene>benzene>toluene. Thus, in the presence of ethanol, xylene is likely to be retarded the least and thus may likely cause greater groundwater contamination than other aromatic kerosene compounds. This increase in contamination is likely to be more with clay than with silt and sand.

\section{Conclusions}

The effect of soil type on the transport and sorption of kerosene compounds in the vadose zone in the presence of water and ethanol was examined using three different soils, namely sand, silt and clay. The aim was to understand the fate of kerosene compounds in the vadose zone after an accidental release on the soil surface. The results obtained show that the transport and sorption of kerosene compounds in the vadose zone will vary with soil type. A total of $11.9 \mathrm{mg} / \mathrm{l}, 8.9 \mathrm{mg} / \mathrm{l}$, and $5.5 \mathrm{mg} / \mathrm{l}$ benzene, $10.9 \mathrm{mg} / \mathrm{l}, 8.6 \mathrm{mg} / \mathrm{l}$ and $6.3 \mathrm{mg} / \mathrm{l}$ toluene, and $12.8 \mathrm{mg} / \mathrm{l}, 8.5 \mathrm{mg} / \mathrm{l}$ and $5.8 \mathrm{mg} / \mathrm{l}$ xylene, were leached from sand, silt, and clay, respectively. On the contrary, a total of $3.0 \mathrm{mg} / \mathrm{kg}, 5.3 \mathrm{mg} / \mathrm{kg}$ and $7.8 \mathrm{mg} / \mathrm{kg}$ benzene, $4.0 \mathrm{mg} / \mathrm{kg}$, $5.5 \mathrm{mg} / \mathrm{kg}$ and $9.6 \mathrm{mg} / \mathrm{kg}$ toluene, and $4.7 \mathrm{mg} / \mathrm{kg}, 6.4 \mathrm{mg} / \mathrm{kg}$ and $9.1 \mathrm{mg} / \mathrm{kg}$ xylene, were retained in sand, silt and clay, respectively. The sorption coefficient $\left(\mathrm{K}_{\mathrm{d}}\right)$ and retardation factor $(\mathrm{R})$ were found to be in the order of clay>silt $>$ sand for soils, and in the order of xylene>toluene $>$ benzene for kerosene compounds, implying that the highest retention will be obtained with xylene in clay while the lowest will be with benzene in sand. The presence of ethanol enhanced the transport of the kerosene compounds but reduced their sorption, $\mathrm{K}_{\mathrm{d}}$ and $\mathrm{R}$, to varying percentages, ranging from 12 to $76 \%$. These effects were generally greatest in sand except in the case of $\mathrm{R}$ where it was 
Citation: Ugwoha E, Nwankwo CA, Okoronkwo CB. Effect of Soil Type on the Fate of Kerosene Compounds in the Presence of Water and Ethanol. J Environ Stud. 2016;2(1): 8.

\section{ISSN: 2471-4879}

in clay, and generally affected xylene more than the other aromatic kerosene compounds.

\section{References}

1. Fine $P$, Graber ER, Yaron B (1997) Soil interactions with petroleum hydrocarbons: abiotic processes. Soil Technol 10: 133-153.

2. Hsieh GC, Parker RD, Sharma RP, Hughes BJ (1990) Subclinical effects of groundwater contaminants. III. Effects of repeated oral exposure to combinations of benzene and toluene on immunologic responses in mice. Arch Toxicol 64: 320-328

3. Khan SR, Nirmal JI, Kumar RN, Patel JG (2015) Biodegradation of kerosene: study of growth optimization and metabolic fate of $P$. janthinellum SDX7. Braz J Microbiol 46: 397-406.

4. Chilcott RP (2007) Kerosene: general information. Version 2. Health Protection Agency.

5. API (2010) Kerosene/jet fuel category assessment document. Submitted to the US EPA. The American Petroleum Institute, Petroleum HPV Testing Group, Consortium Registration \# 1100997.

6. Lam NL, Smith KR, Gauthier A, Bates MN (2012) Kerosene: a review of household uses and their hazards in low- and middle-income countries. $J$ Toxicol Environ Health B Crit Rev 15: 396-432.

7. Hobson GD (1984) Modern petroleum technology, Fifth edition. John Wiley and Sons 1: 189
8. Prasad R (2000) Petroleum refining technology. Knanna Publishers, pp. 402.

9. Ugwoha E (2013) Impact of soil organic matter on groundwater contamination risks for ethanol and butanol blended gasoline. PhD Thesis, University of Nottingham, UK.

10. Myers AL (2002) Thermodynamics of adsorption in porous materials. AIChE J 48: $145-160$.

11. Jaynes WF, Vance GF (1996) BTEX sorption by organo-clays: cosorptive enhancement and equivalence of interlayer complexes. Soil Sci Soc Am J 60: $1742-1749$.

12. Christophersen $\mathrm{M}$, Broholm MM, Mosbæk $\mathrm{H}$, Karapanagioti HK, Burganos VN, et al. (2005) Transport of hydrocarbons from an emplaced fuel source experiment in the vadose zone at Airbase Værløse, Denmark. J Contam Hydrol 81: 1-33.

13. Ugwoha E, Andresen JM (2014) Sorption and phase distribution of ethano and butanol blended gasoline vapours in the vadose zone after release. J Environ Sci (China) 26: 608-616

14. Ugwoha E, Ugbebor JN, Nwosu A (2015) Risk of groundwater contamination by commonly used fertilizers. Biol Forum 7: 29-35.

15. CONCAWE (2001) Environmental classification of petroleum substances: summary data and rationale. Report No. 01/54. Conservation of Clean Air and Water in Europe, Brussels.

\section{Acknowledgements}

The Authors wish to thank the University of Port Harcourt for providing the laboratory where the research was carried out. 